\title{
Designing and Implementing an ESP Course: Revisiting an Experience
}

\author{
Diseño y ejecución de un curso de inglés con propósitos específicos: \\ reconsideración de una experiencia
}

\author{
Elvia Ureña Salazar ${ }^{1}$
}

Recibido: 27/2/2017 / Aprobado: 23/5/2017

\begin{abstract}
This essay pretends to deep on how the process of making decisions in designing an ESP (English for Specific Purposes) course registered by three TESOL graduate students, structured by the author along with participants, a requirement of the Master of English Teaching for Speakers of Other Languages at University of Costa Rica (UCR).

During the course the designers should help a group of UCR workers to communicate in English effectively with international students who want to study at UCR or those who were already participating in international programs. This study introduces data about the apprentices who benefit from this academic activity, tasks designed and taught, as well as the evaluation and assessment used. Finally, it suggests some recommendations for those who may consider the option of designing an ESP course as an effective strategy to promote the use of the target language in a work context.
\end{abstract}

Key Words: Course Design, ESP, language teaching, evaluation and assessment instruments.

\section{Resumen}

Mediante el presente ensayo se pretende profundizar sobre el proceso de toma de decisiones seguido por tres estudiantes inscritos en la Maestría en Enseñanza del Inglés de la Universidad de Costa Rica, durante el diseño de un curso de inglés con propósitos específicos. Este curso fue diseñado por la autora del ensayo y otros dos estudiantes, como requisito de graduación en el programa de Maestría en la Enseñanza del Inglés para hablantes de otros idiomas de la Universidad de Costa Rica (UCR). A través de este curso, los diseñadores debían ayudar a un grupo de trabajadores de la Universidad de Costa Rica a comunicarse efectivamente en inglés con personas interesadas en estudiar en la institución o que estaban participando en programas internacionales. Se presenta información sobre los estudiantes que se beneficiaron de esta actividad académica, las tareas diseñadas y enseñadas, así como los instrumentos de evaluación utilizados. Finalmente, se presenta algunas recomendaciones a aquellas personas que consideran la opción de diseñar un curso de inglés con propósitos específicos como una estrategia efectiva para promover el uso de este idioma en el contexto.

Palabras claves: Diseño de cursos, inglés con propósitos específicos, enseñanza de un idioma, instrumentos de evaluación.

\footnotetext{
${ }^{1}$ Magister en Enseñanza del Inglés. Coordinadora de la carrera de Bachillerato y Licenciatura en Enseñanza del Inglés. Universidad de Costa Rica. Sede del Atlántico, Recinto de Paraíso. Correo electrónico: Elvia.urena@ucr.ac.cr
} 


\section{Introduction}

English for Specific Purposes (ESP) refers to the teaching and learning of the language to a specific group of individuals that have a purpose. In general, this purpose is professional, that is, learners are taught a set of skills that they currently need in their work or will need in their professional career (Day and Krzanowski, 2011). With this idea in mind, this essay analyzes the process followed by a group of graduate students when designing an ESP course for professionals working at the Registrar's Office of the University of Costa Rica, Main Campus (UCR); these officers needed to communicate in English with international individuals who wanted to study at UCR or were already attending classes there.

The instructors of this specific course were three students enrolled in the Master's Program in Teaching English as a Foreign Language at UCR. Two members were international students, and the other was a native Costa Rican who was working in the UCR Office of International Affairs and External Cooperation at that specific time. Therefore, the three knew about some difficulties faced by international students when looking for specific information at the Registrar's Office. Some of these difficulties were directly related to the lack of knowledge of the English language experienced by the officers. The possibility to train these employees with the necessary language was viewed as an opportunity to help narrow that barrier. With the design of specific tasks and with the provision of the specific language, the staff would feel more at ease when communicating with international individuals.

During the last academic year of this Master's Program, students enroll in two courses: Practicum Design and Practicum. The first course requires students to choose a target group, conduct the needs analysis and design the ESP course. To have a group of interested learners is a difficult task for the Master's students. They need to contact the Heads of Departments to see if there is some interest in this academic possibility. Moreover, participants have to take into consideration that attendance is after working hours and voluntary. Once the group is established, the future instructors carry out the needs analysis and design the course program. The designed course is taught during the Practicum. A Practicum supervisor is present in most of the sessions. This supervisor provided feedback to the team regarding such aspects as lesson plan, time management, and teaching strategies. As product of the process explained above, the three graduate students designed the course called "English Language for Registrar's and Information Officers: $\sim$ El RIO $"$. The acronym was elaborated as a strategy to gain the students' identification with the project through a shorter name of the course. El RIO students met twice a week in sessions of two hours; the total number of hours was fifty-four. Each session was taught by one member of the instructing team; the others served as helpers and observers.

\section{English for Specific Purposes (ESP)}

English for Specific Purposes (ESP) is the teaching of this language in direct relation to the learners' working situation. Stevens (1988, in Dudley-Evans and St John 1998) distinguishes between four absolute characteristics and two variable characteristics of ESP. For this author, the four absolute characteristics of an ESP course are:

- its close relation to the specific needs of the learners:

- $\quad$ its content based on disciplines, occupations and activities:

- its concern on centering language to those activities

- $\quad$ its contrast to what has been known as General English

The two variable characteristics of ESP are that the course may be restricted to one language skill and that it may taught without any pre-ordained methodology. Students are expected to learn the language they need to communicate effectively in their job environment. "In contrast to students 
learning English for general purposes for whom mastery of the language for its own sake or in order to pass a general examination is the primary goal, the ESP student is usually studying English in order to carry out a particular role," (Richards, 2001, p. 28). The students participating in El RIO were in charge of providing oral information to English-speaking international students about some processes that take place at the UCR Registrar's Office. Therefore, this approach to language teaching and language learning was specifically useful for the objectives of the three graduate students who had to teach the language in a very specific working environment.

ESP has developed its own methodology, and its research draws from various disciplines in addition to applied linguistics. The main concerns are the needs analysis, text analysis, and making learners ready to communicate effectively in those tasks that are necessary in their study or work situation. The ESP course must comply with such characteristics as meeting the particular needs of the learners, using the implicit methodology and activities of the learners' discipline, and centering the teaching of the language skills (grammar, lexis, register, skills, discourse and genres) appropriate to those disciplinary activities (Dudley-Evans and St John, 1998). In other words, each ESP group of students attends a unique course that has been especially designed for their language needs in a very specific context, while performing certain job tasks. Dudley-Evans and St John (1998 p.5) also indicate that ESP courses also have such variable characteristics as the following:

- ESP may be related to or designed for specific disciplines;

- ESP may use, in specific teaching situations, a different methodology from that of general English:

- ESP is likely to be designed for adult learners, either at a tertiary level instruction of in a professional work situation. It could, however, be used for learners at a secondary school level;

- ESP is generally designed for intermediate or advanced students. Most ESP courses assume basic knowledge of the language system, but it can be used with beginners.

Furthermore, for Day and Krzanowski (2011), ESP courses can also be designed for working professionals; in such case, the course is going to take into consideration the needs of the specific profession as well as those of the specific organization.

Designing an ESP course is described by Dudley-Evans and St John (1998) as a set of phases. For the authors, "the key stages in ESP are needs analysis, course (and syllabus) design, materials selection (and production), teaching and learning, and evaluation. These are not separate, linearlyrelated activities, rather they represent phases which overlap and are interdependent," (p.121). Those phases were the ones the three graduate students followed to come up with "English Language for Registrar's and Information Officers: El RIO ".

\section{Needs Analysis in ESP}

To design an effective ESP course, instructors require knowing the working conditions of the learners as well as their language needs. They also require knowing the tasks that will be performed in English by the students. The needs of the learners are central for the course design. This phase of getting closer to the group's actual situation is called needs analysis. The focus of the needs analysis has changed with time. During the 1960s and early 1970s, it mainly assessed the learners' communicative needs as well as the practices to attain specific teaching objectives; nowadays it aims at gathering information about the learners as well as to define the target situation and environment of studying ESP (Simion, 2015). The information about the prospect learners is crucial during the design 
of the course. Dudley-Evans and St John (1998) state the needs analysis in ESP helps determine the following information about the learners:

- professional information: tasks and activities they will be using English for.

- personal information: factors which may affect their learning (previous experience, cultural information, reasons for attending the course and expectations.

- language information: their current skills and language use

- language lacks in relation to their professional information

- language learning information: what they need to learn

- how language and skills are used in the target situations identified in the professional information.

- expectations about the course

- environment information in which the course will be run.

Accordingly, Day and Krzanowski (2011), consider that there are at least ten vital aspects the EPS teacher needs to know before delivering a course designed in accordance to the learners' preferences. These features can be implemented as questions that need to be answered by the course designers. Paraphrasing these authors, those questions are summarized as follows:

- Is the instructor expected to deliver a tailormade ESP course or is it possible to adapt or modify an existing one?

- Who are the learners?

- Are the learners paying for the course or are they sponsored by their employer? If they are sponsored, the needs analysis should include the expectation of the employer.

- Do the learners expect to be consulted in the process of syllabus design?
- What is the learners' language proficiency level? Are they homogeneous or not?

- What particular forms of the language are used in their specific professional activities?

- Are there extra funds for the design of new materials to supplement the ones that are available?

- Where and how will the course be delivered? Will the learners have enough time for selfstudy or homework?

- What are the learners' learning styles and preferences?

- To what extend is the instructor familiar with the specific subject matter?

The results of the needs analysis will aid the ESP instructor identify valuable information about the students. The teacher will know about their prospective professional needs, their needs in terms of language skills and their deficiencies in language skills. With this information, the instructor can determine the objectives of the language course, and select material that meets those requirements. Therefore, needs analysis is basic to establish curriculum content, teaching materials and methods that will motivate learners (Simion, 2015).

\section{Results of the Needs Analysis}

As stated before, the process of the needs analysis took place during the Practicum Design. The graduate students based their needs analysis on Graves (2000) who states that the main purpose of the needs assessment is to gather information about the learner's abilities, attitudes, preferences before the course and about the desired abilities, change and outcome expected from the academic activity. The needs analysis was conducted to a group of twelve university workers mainly from the Registrar's Office. Some of the relevant results were that their average language proficiency was very low. Learners felt that they needed to learn 
English to give information about admission to UCR and to get the main idea of incoming emails. Learners also wanted to listen to recordings, study grammar and watch videos. They also wanted to talk confidently to English native speakers. The analysis of the assessment allowed the graduate students to conclude that to perform those tasks, the twelve learners also needed to accomplish some other activities as to greet and offer help to English-speaking individuals, get the main ideas and specific information of job-related electronic communications, give directions on the UCR campus, explain the process of enrolling for the Admission Test and applying for transcripts. All these tasks had to be learned in a context where learners would feel comfortable and motivated; therefore, instructors decided that they would use different language learning activities; for example, they would use controlled practice, pair-group work, role plays, speech recording, reading authentic and adapted emails, and keeping language learning logs. Another relevant aspect in the decision - making process was the fact that the ESP course would last only 16 weeks, so the student - instructors decided to work mainly on their speaking skill. This decision was also made because most of the international students asked for help in person. As to their interest and language learning preferences, learners showed that they were very traditional, since they preferred teacher-front classroom activities. Therefore, the instructors had the challenge to create a friendly and trusting learning environment in which students could develop speaking skills such as risk-taking and negotiation of meaning more confidently.

Robinson (1980) in Richards (2001) explains that ESP students usually study to perform a role. The measure of success for these students is whether they can perform convincingly in their working tasks. As stated before, prospective learners perceived that their main language needs were related to the following tasks:
- Giving information about admissions to UCR

- Getting the main ideas of the incoming emails

- Giving directions on the UCR campus

- Applying for transcripts at UCR

Those four main tasks were subdivided into smaller elements that became the course content units. Based on the previous information, the student - instructors concluded that the group of workers of the UCR Registrar's officers needed specific English training to carry on the following job - related tasks:

- Greeting international students and offering help

- Reading job-related texts, e.g. emails, to get the main ideas

- Reading job-related texts, e.g. emails, to get specific ideas

- Locating the main offices of the Administrative Building A

- Locating the main buildings on the UCR campus

- Clarifying information when this is not clear or understandable

- Determining international students'status at UCR

- Relaying the majors provided by UCR

- Relaying the important dates related to the admission process at UCR

- Sending international students to the appropriate office for admission processing

- Explaining the process of enrolling for the Admission Test

- Explaining the process of applying for transcripts

- Explaining the process of admission to UCR 


\section{The ESP Course}

Motivating learners' participation was crucial for the group of Master's students. A strategy to promote a close identification with the proposed course was to denominate the course as: "English Language for Registrars and Information Officers: “ $\sim$ El RIO ." It was conceived as a tailormade ESP program for the registrar officers that voluntarily accepted to participate in the experience. Prospective students were consulted in the process of syllabus design as a strategy to know the tasks they performed in their job environment. This information served to prepare each content unit. Through the different sessions, instructors could learn more about students' learning preferences and styles as well as their language level. All the materials used along this course were provided by the instructors; some were adapted from those used for general English courses to fulfill the purposes of this specific course. Even though the needs analysis was conducted to a group of twelve prospective students, the time the course was implemented, only five individuals started and finished the course; all of them belonged to the Registrar's Office.

\section{Course Design}

Planning a course and designing the syllabus are processes that have different levels of preparation and development that are closely related to the aims and objectives established for the specific group of learners. Richards (2001, p.145) established the different levels of the process:

- Developing a course rationale

- Describing entry and exit levels

- Choosing course content

With these ideas in mind, the group of student-instructors agreed that the fundamental purpose of El RIO was to help registrar officers overcome the necessity to communicate in English with international students who went to the UCR Registrar's Office. The different steps recommended by Richards (2001) were core activities of the Practicum Design Course.

During the course design process, the student - instructors constantly met with the potential students to have a clear idea of those processes carried out in the UCR Registrar's Office. Those processes were subdivided into phases which were relevant to defined the different teaching units. Each unit had one general objective with its corresponding specific objectives. Additionally, each unit was divided into different tasks that the student had to perform along the course to attain the proposed goals. The five general and the corresponding specific objectives are presented as follows:

Unit 1: Explaining the UCR Admission process to international students

\section{General Objective:}

Students will be able to confidently provide precise information about the UCR admission process to English - speaking individuals

\section{Specific Objectives}

Students will be able to:

- greet English - speaking people and offer help.

- classify the different types of international students that attend UCR and provide an adequate initial answer according to the inquiries they get.

- identify and pronounce the different names of the majors taught at UCR.

- to indicate the dates and periods related with the admission process to the UCR to those English -speaking individuals wishing to attend the UCR as regular students. 
Unit 2: Handing in the corresponding documents to international students

\section{General Objective:}

Students will be able to provide English- speaking individuals the documents they ask.

\section{Specific Objectives}

Students will be able to explain to international students at UCR the necessary procedure to ask for certifications and / or copies of their records.

Unit 3: Giving directions to international students

\section{General Objective:}

Students will be able to accurately give directions in the UCR Main Campus in English.

\section{Specific Objectives}

Students will be able to:

- indicate to English - speaking individuals the location of the most important buildings, using a map of the UCR Main Campus.

- indicate to English - speaking individuals the location of some offices in the Administrative Building A.

Unit 4: Reading job - related material

\section{General Objective:}

Students will be able to read job - related English material.

\section{Specific Objectives}

- read electronic mails and understand the main idea.
- respond in writing to the requests made through electronic mail by English speaking individuals

Unit 5: Communicating in English confidently

\section{General Objective:}

Students will be able to pronounce the English language confidently and be willing to take linguistic risks during class activities, with motivation and a positive attitude towards the learning of the English language.

\section{Specific Objectives}

Students will be able to:

- take risks to negotiate meaning with English - speaking persons.

- confidently pronounce the English language

\section{Task Definition}

After establishing the five units with its corresponding general and specific objectives, the three instructors determined the different tasks that would be performed by the students to attain the established goals. What follows is the list of those specific tasks:

- Introducing oneself

- Offering help to international students

- Classifying international students

- Asking questions to classify international students

- Where to send the international students to get help

- Numbers review

- Locating important offices in the administrative building $\mathrm{A}$

- Describing locations of buildings 
- Getting around the UCR campus \& analysis of the role-play

- Giving directions on campus

- Analyzing my progress

- Using strategies to read emails \& giving directions on campus

- Signing up for the admission exam

- Explaining the process of admission to UCR

- Explaining the process of document certification

- $\quad$ Creating small talk \& building empathy

It is important to mention that depending on the complexity of each task, the time devoted to cover it could have included more than one week. For example, for Unit 1, they decided to dedicate 8 weeks, while for Unit 2 just one. In addition, during the whole course, the instructors promoted constant recycling of the language studied as well as the students' self-awareness of what they were learning.

The contents of the syllabus reflected the students' workplace discourse; it incorporated workrelated negotiations of meaning and interactions that students would recognize as familiar.

\section{Material Design}

All materials used in class were provided by the group of instructors, who prepared them in such a way that students would be able to work on each step using their target language. In most of the cases, they adapted those used for courses of general English to suit the needs of this specific instance. During the first day of class, for example, students practiced the Alphabet (Unit 1, Lesson 1: Introducing Oneself), and to practice it in pairs, they received a list with the names of some majors taught at UCR. As part of the exercise, they were asked to work in pairs and take turns and spell each major to one another. This means that instructors were very careful while designing / adapting the materials to include the target language and promote its use in the specific working tasks. This is clearly explained by Dudley-Evans and St John (1998), when they say: "ESP practitioners often have to plan the course they teach and provide the materials for it. It is rarely possible to use a particular textbook without the need for supplementary material, and sometimes no really suitable published material exists for certain of the identified needs," (p.14).

\section{Methodology}

As mentioned above, El RIO was an ESP course designed in accordance to the most relevant tasks identified through the needs analysis applied to the group of UCR workers willing to participate in this Practicum experience. The methodology adopted for this teaching project was mainly based of the Task-Based Language Teaching Approach (TBLT). This approach is based on the identification of different tasks that would be basic for the planning and instruction of the language. Richards and Rogers (2001, p. 223) state that these tasks are proposed as useful instruments to apply vehicles for applying the following Communicative Language Teaching principles:

- Activities that involve real communication are essential for language learning.

- Activities in which language is used for carrying out meaningful tasks promote learning.

- Language that is meaningful to the learner supports the learning process.

EL RIO tutors designed the course using the learners' working tasks as starting points. The instruction used realistic, authentic student-centered activities grounded in the communicative language teaching foundation. Since the course lasted only 14 weeks, the teachers decided to promote the learning of "language chunks" or prefabricated routines that enabled transactionally focused conversations with 
English speakers. They also decided to use some principles of such other approaches and methods as Communicative Language Teaching, Total Physical Response, and Cooperative Language Learning. For, Nalan (2015) "In ESP any method can be chosen to be used in the classroom according to the context, learners, and needs analysis, teaching standard and learning abilities. There is no difference between EFL and ESP in teaching method. However, ESP teachers need to integrate the content and the language (Nalan, 2015, para. 10). Therefore, the decision made by the group of instructors at the time of the Practicum was correct.

\section{Evaluation}

The group of instructors used several instruments and strategies to evaluate the students' progress along the course.

- Language - Learning Log: every week, students had to fill out a form with phrases and expressions they learned during that specific week. They also had to mention those aspects that presented some problems for them as well as to include some phrases and expressions they would like to learn in the course. Through this instrument, the teaching team could assess if the use of vocabulary and structures studied was correct or not. During the subsequent planning sessions, the team analyzed the logs and designed several activities to provide feedback accordingly.

- Role plays: the development of the speaking and listening skills was the main focus of the course; learners were continuously asked to make up and present conversations. The instructors provided feedback to students regarding the strategies used to convey meaning as well as language use.

- Techno- Homework: students were asked to keep an electronic reflection journal about their learning process. They also received electronic messages from their instructors, and they had to answer back to them. The electronic reflection was reviewed on a weekly basis. Since students' language proficiency was very low, they could write their reflections in Spanish. The main objective of this activity was to give the opportunity to express feelings regarding the learning process.

- Audio and Video Recordings: The midterm evaluation was based on analyzing the students' oral performance while helping international students at the window. Students were taken to their job area and were asked to help international students who would approach the window asking for specific information. The international students were the two members of the teaching team and a guest. The activity was taped. The information provided by the recording helped the instructors to design several activities to work on such areas as communication strategies used during the conversations, content, language use, and pronunciation. These activities were incorporated in the subsequent lesson plans.

- Portfolio: Students kept a portfolio with all the material used in class, their reflections on their learning process and their vocabulary lists.

- Final Oral Project: At the end of the course, as a requirement of the Practicum course, learners had to present an oral activity that would show how much they had learned along the course. This activity would be attended by the Practicum professors and the students enrolled in the Practicum. To lower their anxiety, learners rehearsed a conversation that would take place between an international student and an employee from the UCR Registrar's Office. This conversation was recorded by the instructors and was used to provide feedback. The Practicum professors considered the presentation a success. The result was due to hard work and continuous practice. 


\section{Recommendations}

The main purpose of the present essay was to revisit the experience of three UCR graduate students when designing and implementing an ESP course. One of the obstacles faced was the consolidation of the group of potential pupils. The first step was to visit the authorities of several UCR offices to offer a "free" English course and ask for their permission. If the authority agreed on allowing the implementation of the course, the next step was to convince the workers to attend. Those stages were not easy because to enroll in such a course meant to stay after work, two times a week for two hours. This situation could be lessened if the graduate students had the possibility to look for pupils in other public institutions. The coordinators of the Master's program could; for example, establish cooperation agreements with public institutions interested in training their workers. Another difficulty faced by the three instructors was the risk of not being able to implement the lesson plan. This was mainly because participation was voluntary. In the experience subject of the present essay, there were instances in which only one student showed up to class, forcing an abrupt change in the lesson plan. This situation also risked the instructors' grades in the Practicum course because their practice was supervised and grades by UCR professors as part of the requirements of the course. Therefore, there is a need to promote a sense of commitment among the participants.

When looking for prospective learners, there is the possibility of creating some expectations that the course could not fulfill during the fourteen - week ESP course. Therefore, the course syllabus should be elaborated, revised and approved not only by the instructors, but also by the prospective learners. This would motivate both groups of participants since the academic project could be considered as theirs, and the expectations would be shared. The course syllabus should be organized in such a way that continuous recycling of language structures and content is promoted.
The seriousness and amount of effort put in the design of this kind of courses deserve to be considered when initiating the proposal for a similar course. Therefore, the results of this experience, which are kept in the University Library, could be taken as the starting point for other similar courses. For example, a group of graduate students interested on teaching ESP to a group of Registrar's officers could take this essay as a starting point. During the process of elaborating their own academic activity, they could contact the authorities of the of the Registrar's Office and the Office of International Affairs and External Cooperation (OIAEC) to check if the identified tasks still apply to the needs of the prospective learners. Their needs analysis could result on the proposal of more tasks that need to be considered during the course design.

Finally, some research should be done on the results of the ESP courses elaborated in the frame of the Masters in English Teaching for Speakers of Other Languages at the University of Costa Rica to evaluate the effectiveness of such practice in the groups involved: the practitioners and the students.

\section{References}

Day, H. and Krzanowski, M. (2011). Teaching English for Specific Purposes: An Introduction. Cambridge, UK. Cambridge University Press.

Dudley - Evans, T. and St John, M.J. (1998). Developments in English for Specific Purposes: A multi-disciplinary approach. Cambridge, UK. Cambridge University Press.

Graves, K. (2000). Designing Language Courses: A Guide for Teachers. Boston, MA. Heinle \& Heinle.

Lee, J., Sandru, J.N. and Ureña, E. (2003). Práctica Profesional. English Language for Registrars and Information Officers “ $\mathrm{El}$ RIO ". Unpublished Master's Final Graduation Project, Graduate School University of Costa Rica. 
Nalan, E.K. (2015). Is There a Specific Methodology for ESP? Retrieved from: https://www. linkedin.com/pulse/specific-methodologyesp-nalan-eren-kenny

Richards, J. (2001). Curriculum Development in Language Teaching. Cambridge, UK. Cambridge University Press.

Richards, J. and Rodgers, T. (2001). Approaches and Methods in Language Teaching. Second Edition. Cambridge, UK. Cambridge University Press

Simion, O. (2015). Needs Analysis in English For Specific Purposes. Annals of the "Constantin Brâncuşi”" University of Târgu Jiu, Economy Series, 1(2). Academica "Brâncuşi”" Publisher. Retrieved from: http://www.utgjiu.ro/revista/ ec/pdf/2015-01.Volumul\%202/08_Simion.pdf 